\title{
ENTOMOLOGY
}

\section{The first record of grass-living thrips, Chirothrips hamatus (Thysanoptera: Thripidae) in Iran}

\author{
S. Mombeini, ${ }^{1}$ L. Ramezani, ${ }^{1}$ K. Minaei ${ }^{2}$ \\ ${ }^{1}$ Department of Plant Protection, College of Agriculture, Ramin Agriculture and Natural Resources University of \\ Khuzestan; ${ }^{2}$ Department of Plant Protection, College of Agriculture, Shiraz University, Shiraz, Iran
}

\begin{abstract}
Species of the genus Chirothrips Haliday live on various species of grasses (family Poaceae). In this research, Chirothrips hamatus Trybom is reported for the first time in Iran as the seventh species recorded in this country for the genus so far. Most specimens of $C$. hamatus were collected on Phragmites sp. in Khuzestan Province (Iran). As for Chirothrips atricorpus Girault that has been previously reported in Iran the second antennal segment in C. hamatus is symmetrical. The morphological differences of these two species are discussed and illustrated herein.
\end{abstract}

\section{Introduction}

Grasses (Poaceae family) support a rich fauna of thrips; namely, at least 300 species of thrips are fully dependent on grasses and

Correspondence: Kambiz Minaei, Department of Plant Protection, College of Agriculture, Shiraz University, Shiraz, Fars Province, 65, Iran.

E-mail: kminaei@shirazu.ac.ir

Key words: Chirothrips; Grass; Iran; Khuzestan; New record.

Acknowledgments: we are grateful to L. A. Mound (CSIRO, Canberra, Australia) for help us in the identification of the species discussed in this paper.

Contributions: the authors contributed equally.

Conflict of interest: the authors declare no potential conflict of interest.

Received for publication: 14 December 2016.

Revision received: 31 January 2017.

Accepted for publication: 12 February 2017.

CCopyright S. Mombeini et al., 2017

Licensee PAGEPress, Italy

Journal of Entomological and Acarological Research 2017; 49:6476

doi:10.4081/jear.2017.6476

This article is distributed under the terms of the Creative Commons Attribution Noncommercial License (by-nc 4.0) which permits any noncommercial use, distribution, and reproduction in any medium, provided the original author(s) and source are credited. bamboos (Mound, 2011). The grass-living habit has evolved in three families, including Aeolothripidae, Phlaeothripidae and Thripidae. Among them, the largest diversity of Thysanoptera species associated with grasses, occurs in the Thripidae family (Mound, 2011). One of these genera, Chirothrips Haliday with 44 species (ThripsWiki, 2016) is mostly reported from the temperate regions of the world. These thrips breed within the florets of Poaceae, usually with only one larva in each floret (Nakahara \& Foottit, 2012). They have a characteristic body form, including: pronotum trapezoidal with two pairs of postero-angular setae, the small head, the rather stout fore legs and short antennae in which the second segment is usually asymmetric (Minaei \& Mound, 2010; Nakahara \& Foottit, 2012).

Besides the world key by zur Strassen (1960) for the genus Chirothrips and the work by Bhatti (1990) in which several genera were erected in the Chirothrips-like species, a few studies on this group have been recently conducted around the world. Mound \& Marullo (1996) treated seven species in Chirothrips from the Neotropics. Fifteen species have been treated on this group from Europe (zur Strassen, 2003). Nakahara \& Foottit (2012) reviewed the species of Chirothrips and related genera occurring in the Americas and seventeen Chirothrips species have been retained in Chirothrips.

In Iran, 44 genera of Thripidae in four subfamilies (Dendrothripinae, Panchaetothripinae, Sericothripinae, Thripinae) are recognised (Minaei, 2013; 2016); among them about $40 \%$ live on grasses (Minaei \& Alichi, 2013). Moreover, the Chirothrips-like species in this country are known by three genera, including Arorathrips and Olescharda (each with one species) (Minaei \& Alichi, 2013; Fekrat et al., 2016), as well as Chirothrips (with 5 species and one species-group). Despite that, there is no evidence about these species pest status. However, at least one species, Chirothrips manicatus (Haliday), is widely reported as a pest of grasses in New Zealand (Doull, 1956; Bejakovich et al., 1998), in the USA (Rao \& Alderman, 2005) and in Japan (Ishii \& Kadono, 2002).

The objective of this paper is to record another species in Chirothrips based on specimens recently collected in Khuzestan Province, south of Iran.

\section{Materials and Methods}

The thrips were collected into ethanol and then mounted into Canada balsam. The slides were studied using an Olympus BX53 phase-contrast microscope (Olympus, Tokyo, Japan); all measure- 
ments as well as photomicrographs were obtained using this microscope with a DP27 digital camera, using cellSens software. Most specimens are deposited at the Department of Plant Protection, Shiraz University, Iran (PPSU), with a few deposited in the Department of Plant Protection, Ramin Agricultural and Natural resources University of Khuzestan, Molasani, Iran.

\section{Results and Discussion}

The species discussed in this paper is described from Europe (ThripsWiki, 2016). However, it has been reported from North America (Canada) as well (Heming, 1985). All Chirothrips species are associated with the plants in the family Poaceae. Most specimens reported in this paper have been collected on Phragmites sp. However, a few specimens discussed in this paper have been also collected on Lactuca sp. (Asteraceae) and Atriplex sp. (Chenopodiaceae). It seems that both plants have not play a role as host of the Chirothrips species. The precise host plant recognition in Thysanoptera is difficult to be found (Mound, 2013).

\section{Chirothrips hamatus Trybom}

Chirothrips hamatus Trybom, 1895: 187.

\section{Female macroptera}

Body generally brown, tarsi and antennal segment III and VIVIII a little paler; fore wings and clavus weakly shaded. Head weakly produced in front of the eyes (Figure 1A); vertex with two pairs of setae, ocellar setae lateral to fore ocellus. Antennae 8-segmented (Figure 1E), II symmetrical; III and IV with stout simple sensoria. Pronotum trapezoidal with 2 pairs of posteroangular setae (Figure 1C). Fore legs well developed, apical margin of fore femora with a hook (Figure 1B). Mesonotum with transverse sculpturing, partially reticulated; with a pair of campaniform sensilla. Metanotum irregu-

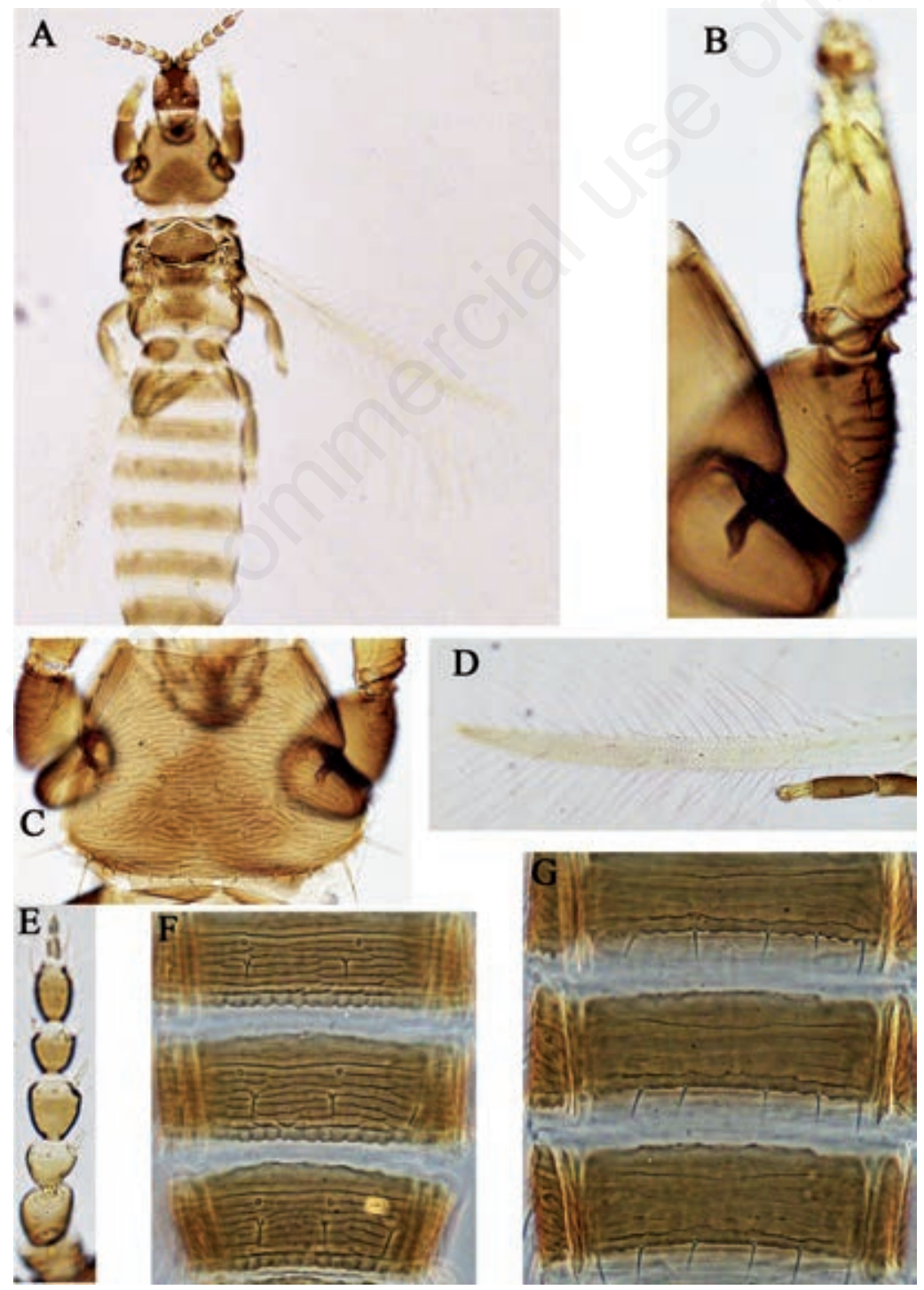

Figure 1. Chirothrips hamatus, female. A) Adult; B) fore leg; C) pronotum; D) fore wing; E) antenna; F) abdominal tergites 5-7; G) abdominal sternites 4-6. 
larly reticulate medially, lateral sculpture lines longitudinally aligned, a median setae near anterior margin, campaniform sensilla present (Figure 2A). Prosternal ferna divided medially; basantra membranous, without setae; prospinasternum well developed transverse band with conical spina (Figure 2B). Mesothoracic sternopleural sutures complete. Meso and metasternal furca with well-developed lateral flanges, without spinula. Fore wing pointed at apex (Figure 1D), first vein with 2-3 setae on distal half, second vein with 5-6 setae. Tergites with many transverse lines medially, the tergal craspedum is entire with a lobed margin; campaniform sensilla on abdominal tergites anterolateral to median setae (Figures $1 \mathrm{~F}$ and 2C). Ovipositor moderately developed and bearing rows of teeth. Sternites with 3 pairs of marginal setae; posterior margins medially has few or only small rounded tubercles (Figure 1G).

\section{Remarks}

In most Chirothrips species, the antennal segment II is asymmetrical (produced laterally or angulate) and this situation is true for five out of six Chirothrips species in Iran (Minaei \& Mound, 2010). However, in a few species this segment is symmetrical. $C$. hamatus is only the second Iranian species with symmetrical antennal segment II. The other one is C. atricorpus. C. hamatus is readily distinguished from $C$. atricorpus by a remarkable hook which is located on the external of fore femur (Figure 1B) (versus C. atricorpus has the fore femur external apex without a hook).
Moreover, the tergal craspedum is entire with a lobed margin, and the sternite posterior margin medially has few or only small rounded tubercles whereas $C$. atricorpus has the tergal craspeda are composed of a series of independent lobes, and the sternites bear long rather pointed lobes. Also, in contrast to C. atricorpus, campaniform sensilla on abdominal tergites are anterolateral to median setae in $C$. hamatus but these sensilla in $C$. atricorpus are posterolateral to median setae. Finally, the external margins of the fore femora and tibiae appear to be rugose due to the very strong margins of the sculptured reticles that are prominent in lateral view in C. hamatus (Figure 1B).

\section{Measurements}

One female, in microns. Body length 910. Head, length (width across cheeks) 78 (157). Pronotum median length (width) 92 (183). Fore wing length 6665. Tergum IX median length S1 setae length 40, S2 setae length 43. Ovipositor length 160. Antennal segments I-VIII length: 22, 26, 30, 28, 26, 22, 9, 11.

\section{Material studied}

Iran. Khuzestan Province, Mollasani (about 30 Kilometers northeast of Ahvaz), 2 females on Atriplex sp., 3.vi. 2014 (Saeideh Mombeini); the same place, 1 female on Lactuca sp., 25.v.2015; the same place, 5 females on Phragmites sp., 26.x.2015 (Saeideh Mombeini).
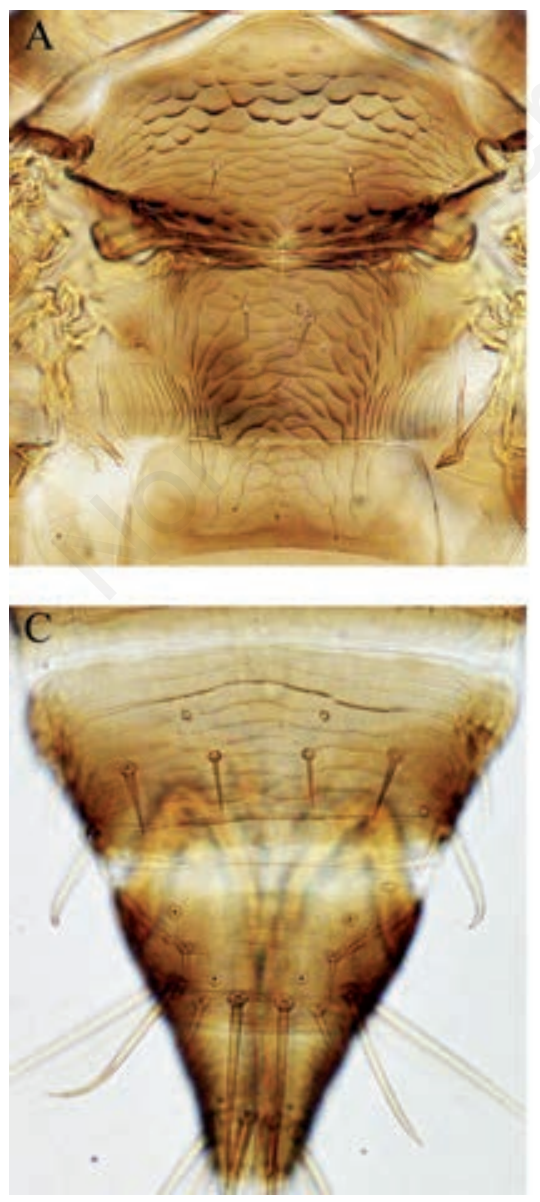

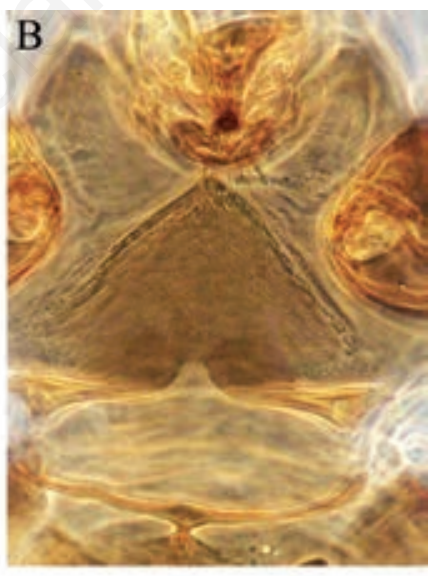

Figure 2. Chirothrips hamatus, female. A) Meso \& metanotum; B) prosternum; C) abdominal tergites 8-10. 


\section{References}

BEJAKOVICH D., PEARSON W.D., O'DONNELL M.R., 1998 Nationwide survey of pests and diseases of cereal and grass seed crops in New Zealand. 1. Arthropods and molluscs. Proc. 51st N.Z. Plant Protection Conf. 38-50.

BHATTI J.S., 1990 - On some genera related to Chirothrips (Insect: Terebrantia: Thripidae). - Zoology (JPAZ. 2: 194-200.

DOULL K.M., 1956 - Thrips infesting cocksfoot in New Zealand II. The biology and economic importance of the cocksfoot thrips Chirothrips manicatus Haliday. - NZJ Sci. Technol. Sect. A. 38: 56-65.

FEKRAT L., HOSSEININEJAD M., DERAKHSHAN A., MINAEI K., 2016 - Grass-thrips of the genus Oelschlaegera (Thysanoptera: Thripidae), with the first description of a male. - Zootaxa 4105: 296-299.

HEMING B.S., 1985 - Thrips (Thysanoptera) in Alberta. - Agric. Forest. Bull. 8: 19-23.

ISHII J., Kadono Y., 2002 - Factors influencing seed production of Phragmites australis. - Aquat. Bot. 72: 129-141.

MINAEI K., 2013 - Thrips (Insecta, Thysanoptera) of Iran: a revised and updated checklist. - Zookeys 330: 53-74.

MINAEI K., 2016 - [Thrips, minute insects but opportunist]. Shiraz University Press, Shiraz, Iran [in Persian].

MINAEI K., ALICHI M., 2013 - The grass-living thrips (Insecta: Thysanoptera) from Iran with the first record of the genus Arorathrips Bhatti. - J. Entomol. Acarol. Res. 45: 65-68.

MINAEI K., MOUND L.A., 2010 - Grass-flower thrips of the genus Chirothrips (Thysanoptera: Thripidae), with a key to species from Iran. - Zootaxa 2411: 33-43.

MOUND L.A., 2011 - Grass-dependent Thysanoptera of the family Thripidae from Australia. - Zootaxa 3064: 1- 40.

MOUND L.A., 2013 - Homologies and host-plant specificity: recurrent problems in the study of thrips. - Fla. Entomol. 96: 318-322.

MOUND L.A., MARULLO R., 1996 - The Thrips of Central and South America; an introduction (Insecta: Thysanoptera). Associated Publishers, Gainesville, Florida, 487 pp.

NAKAHARA S., FOOTTIT R.G., 2012 - Review of Chirothrips and related genera (Thysanoptera: Thripidae) of the Americas, with descriptions of one new genus and four new species. Zootaxa 3251: 1-29.

RAO S., ALDERMAN S.C., 2005 - Infestation of Bent Grass by a New Seed Pest, Chirothrips manicatus (Thysanoptera: Thripidae), in Oregon. - J. Entomol. Soc. B. C. 102: 77-78.

THRIPSWIKI 2016 - ThripsWiki-providing information on the World's thrips. Available from: http://thrips.info/wiki/ (accessed 10 Nov. 2016).

TRYBOM F., 1895 - Iakttagelser om vissaq Bläsfotingars (Physapoders) upträdande I grässens Blomställningar. Entomol. Tidskr. 16: 157-194.

ZUR STRASSEN R., 1960 - Key to and catalogue of the known species of Chirothrips Haliday, 1836 (Thysanoptera: Thripidae). - J. Entomol. Soc. South Afr. 23: 144-176.

ZUR STRASSEN R., 2003 - Die terebranten Thysanopteren Europas und des Mittelmeer-Gebietes. - Die Tierwelt Deutschlands und der angrenzenden Meeresteile. 74: 1-277. 